\title{
1
}

\section{Diversity and Its Discontents: Rays of Light in the Faculty Development Movement for Faculty of Color}

\section{Edith A. Lewis}

University of Michigan

Two faculty development conferences beld within a six-day period during October 1998 yielded important experiences and lessons for faculty and professionals interested in working with faculty of color. This paper, written from the standpoint of a faculty member of color, outlines the strengths and challenges of working on these issues in higher education institutions.

\section{INTRODUCTION}

Tournal entry, Saturday, October 18, 1998, 6:45 p.m. EST. I am on a $\int$ flight between Salt Lake City, Utah, and Minneapolis, Minnesota, moving between two conferences focusing on faculty development issues. The first conference is sponsored by the professional organization of faculty development personnel, while the second conference is dedicated to the retention and recruitment of faculty of color in higher educational institutions. In many ways this flight is a tangible expression of the differences in the two cities and, I expect, the two conferences.

I had originally been seated with a family with small children and was having a bit of difficulty concentrating on some writing I intended to complete before we landed in Minneapolis. In mid-flight, one of the passengers, who also attended the first conference in Salt Lake City, passed through the cabin and informed me that the flight had a number of empty seats in its rear, and that I might have a more pleasant ride if I 
chose a different part of the airplane. After checking with the flight attendant, I moved to change my seat and give the family some additional space.

A quick glance around the plane yields the bonanza of a full bank of seats in an exit row of the airplane, with plenty of legroom. This part of the plane is also virtually empty, with the exception of a couple sitting across the aisle in another exit row, and the family seated behind them. As soon as I choose a vacant row in the exit aisle across from the couple, the silence in the area I have chosen changes dramatically. The woman across the aisle (who had been resting her head on her male companion's shoulder until I sat down) hops out of her seat, begins muttering something to the man she is seated with and points at me. I'm a bit tired of negative confrontations after the first three days of this trip and choose to simply ignore her. Eventually she gathers her things and, in an extremely agitated state, moves, apparently, to another seat. The man just stays and continues to sleep. Approximately 30 minutes later, however, the woman returns and wakes him up. She again points to me and then to other vacant seats near the galley of the airplane. By now, the woman is visibly angry and loudly says something about my interfering with her ability to stay in this aisle and her assigned seat. After a moment, the man shrugs his shoulders, collects his belongings, and moves with her to another place on the airplane.

Accustomed to this type of response over the past three days, I go through the inventory to make certain that my perceptions of why this woman moved were accurate. I had bathed that morning; I hadn't had a drink of alcohol in over 25 years so l'm not drunk; I'm not playing loud music; and I'm not flirting with her male partner. I am dressed as the university professor that I am and am working on a quiet laptop computer. Still my presence is repugnant and odious. I view the experience as my "racial slight of the day" and move on. Later, when the flight attendant comes with the food cart, I ask her what reason the couple had given her for changing seats. Her response was that the children in the seats behind the couple were kicking her seat and made her uncomfortable. Why, then was she pointing at me? Is this healthy cultural paranoia?

In some ways, this flight might as well have been between two worlds, rather than two cities, as it bridges two distinct perspectives on the importance of doing faculty development work with faculty of color across the country. At one end of the bridge are those who believe that faculty of color have the exact experiences of white faculty and that there is no need for attention to issues of diversity or multiculturalism within 
the faculty development field. In fact, at one of the conferences, findings from a national study of faculty developers place issues of diversity at the bottom of the list of priorities for faculty developers (Wright, 1998). The "no difference, no need" perspective extends beyond issues of race and ethnicity to include similar mindsets on class and sexual orientation. At the other side of the bridge is the perspective that the most important issue for retaining faculty of color is the existence of faculty development programs geared directly to their needs (Myers, 1998). This perspective might otherwise be termed "important difference, critical need."

Thus, this is a story about the bridge of diversity for faculty of color in higher education and my six-day experience of moving across it at a unique time period when two conferences on faculty development were being held within the same week. While the experience is generally related in its chronological order, it also attempts an analysis of the week in relation to some of the literature on individual and organizational change. This is a story about how difficult the experience of the "no difference, no need" perspective can be for faculty of color, even when they have experienced, and the scholarship supports, the likelihood of reactance by faculty colleagues and administrators in higher education when issues of diversity are raised. It is also a story about how vital it is for faculty of color to have programs and places in which the "important difference, critical need" experiences may be addressed.

Most importantly, however, it is a story of the moments of transformation that make it possible for those interested in diversity issues to continue to do our work. Transformation can occur in many forms, and this paper provides two examples in very different contexts-one geared toward the "general population" faculty developers and the other focusing directly on the faculty development needs of faculty of color. It is those transformative "rays of light" that, in touching even one mind, have ripple effects on the ways organizations, programs, and educational institutions operate (Gutiérrez \& Lewis, 1999).

\section{The POd Conference and the Challenge of Placing Diversity at THE Forefront Of THE Agenda}

\section{The Opening Plenary: Preaching Without the Choir}

There is an old phrase used in my community of origin, "preaching to the choir." It refers to making presentations or disseminating material to an audience that has some familiarity with it. While the phrase "preaching to the choir" suggests that the recipient group or audience is somewhat 
supportive of what they are hearing, it by no means requires complete and total agreement with the speaker, as any minister waiting for an "amen" from their congregation can testify.

Those doing diversity work often experience preaching without a choir. As we enter new situations, it is helpful but not always possible to have an in-depth understanding of the set of interactions we are about to join. This is true in organizational as well as interpersonal contexts. My entrance into the Professional and Organization Development Network in Higher Education was to be more of an experience of preaching without a choir than I had seen in over a decade.

The Professional and Organizational Development Network in Higher Education (POD) is an organization that comprises faculty development specialists from across North America. POD members meet annually to share information across their programs about what they hope are the most exciting innovations in faculty development work. This includes the findings from programs as well as research on teaching, student assessment, classroom climate, and faculty recruitment and retention. POD also annually publishes a resource volume entitled To Improve the Academy, which offers valuable assistance to anyone interested in faculty development at higher educational institutions.

POD's mission statement, adopted in 1991, includes the following:

POD believes that people have value, as individuals and as members of groups. The development of students is a fundamental purpose of higher education and requires for its success effective advising, teaching, leadership, and management. Central to POD's philosophy is lifelong, holistic, personal and professional learning, growth, and change for the higher education community (see p. vi, this volume).

While this is the organization's 23 rd year, I have only recently learned of its existence. My connection with POD has been stimulated by my work as the Multicultural Faculty Associate in the University of Michigan's Center for Research on Learning and Teaching (CRLT). Staff from this well-respected unit have been active in POD for many years and have made significant contributions to the development of the organization. In fact, I have become interested in the POD network precisely because of the leadership its founders and current staff have had in the organization.

During the summer of 1997, while working with CRLT colleagues on 
their first Summer Multicultural Institute, I met trainers and administrators from other faculty development programs across the country who provided more information about POD. One of these individuals invited me to participate on a plenary panel she was organizing for the 1998 conference. The conference theme for 1998 , "Collaborations, Connections, and Community," intrigued me. It focused on the linkages between diversity and community in higher educational institutions. Coincidentally, my CRLT colleagues asked me to participate in a workshop they had organized on using Intergroup Dialogue (Zúñiga \& Nagda, 1993) as one method for addressing issues of difference in the classroom.

One of the concerns expressed by the POD members who invited me to attend the conference is the lack of attention to issues of "diversity" among the membership. I had interpreted this concern to refer to a wide range of diversity issues including the social group memberships of race and ethnicity, sexual orientation, and gender. Furthermore, the social group membership of economic class is almost entirely omitted from discussions of diversity but continues to present an issue for those members of higher educational institutions who are from working class or more impoverished backgrounds (Lewis, 1993). Literature in this area suggests that it is far easier to discuss gender diversity than racial/ethnic or sexual orientation diversity in organizations (Adams, 1992; FigueiraMcDonough, 1998; Icard, Jones, \& Wahab, 1999; Schoem, Frankel, Zúñiga, \& Lewis, 1993). As research on social group memberships has now embraced the development of measurement tools for the construct of "intersectionality" - that is, the simultaneous embodiment of several "different" social group memberships (e.g., being a lesbian woman of color from an upper-income family background)-knowing "what to do" as a faculty member also becomes increasingly complex (Adams, 1992; Bell, Washington, Weinstein, \& Love, 1997; Icard, Jones, \& Wahab, 1999). My personal experience as a trainer in this area for over 20 years also supports these findings. Moreover, my experience as a faculty member working with other faculty members on several campuses has helped me to understand that what the behavioral sociologists, social workers, and psychologists have documented about "diversity discomfort" is not restricted to those outside of the academy (Davis, 1998). When I accepted the invitation to participate in the conference to discuss the linkages between faculty development and diversity, I assumed that the discomfort with various types of diversity would continue to be the case at this conference. 
In fairness, some POD members have joined the choir in their home institutions through the years. There are, for example, individual POD members who have worked tirelessly to bring the discussion of diversity to POD meetings and literature. The organization also has a Diversity Commission, and the group has been quite busy developing an outstanding program on the conference theme. In addition to addressing the issue of diversity through conference presentations, several faculty of color involved with faculty development work on their own campuses had been invited to the 1998 meeting and asked to consider joining POD. These efforts, and the discomfort of some POD members about the issues of diversity being discussed at the conference, formed the two ends of the bridge framing the 1998 annual conference.

The panel I had been asked to participate in was the opening plenary held after dinner on the first evening of the conference. The five panel members had been meeting via electronic mail and telephone during several months before the conference to plan our session. We represented institutions from all regions of the US, different disciplines, and diverse social group memberships. We also represented vastly different philosophical positions with regard to our subject matter, and our discussions had been quite lively. Using a prepared set of questions, we decided to share the discussions we had been having with the audience of 497 registered participants. The decision allowed us to model for the audience the utility of dialogue about the delicate topics included in a discussion of diversity issues. How, for example, is unity possible with a focus on diversity? How do different definitions of community influence our behavior in working on college and university campuses? What have we learned from our experiences in helping to shape diversity agendas on our respective campuses? What findings could we share with our colleagues about "best practices" in this work?

One of the phrases I often use in teaching is "where you stand determines what you see." Having had little prior exposure to POD, I believed that the plenary had generally been well received and provided several provocative questions that could be addressed throughout the remainder of the conference. I learned later that approximately one-third of the participants left the room immediately after completing their dinner and did not stay for the plenary session. Even more ominous was the warning a colleague on the panel gave me as we prepared to leave the ballroom stage: "There will be a backlash from this."

Those working on faculty development issues that address the particular experiences of diverse populations should always be on the lookout 
for what I often term "the backlash" from non-choir members (Gutiérrez \& Lewis, 1997). Rooney (1992), in fact, suggests that this reaction is to be expected from individuals placed in involuntary situations. Recognizing as normal the feelings and behaviors of those encountering new information about racial, ethnic, gender, sexual orientation, and class diversity allows faculty developers (and faculty in the classroom) to continue their work while the process of learning takes place (Lewis, 1993). After the plenary, lacking a former standing place to serve as a baseline, I was unable to "see" in advance how intense the backlash would be.

\section{The Backlash}

The conference's second plenary session was held after lunch the next day and was titled Student Evaluation of Teaching for Summative Purposes: What Collaborative Roles Can Developers Play? This session, I had been told, was my opportunity to hear several of the founders of the faculty development movement in higher education speak. I also looked forward to the event because I would have a chance to hear a colleague with whom I had a more personal relationship speak for the first time in many years.

My pleasure at attending the session was short-lived. The first speaker began his comments by linking criminal behavior with African-Americans. When this first happened, I thought I had surely misunderstood what he had said. As he continued with this racist (in the classic definition of individual racism) analogy, I began to look at others at my table for some type of guidance. At last, one of the people at my table leaned over and whispered, "He comes from one of the most conservative schools in California." This saddened me deeply, as I had hoped that the person was not using the analogy as a weapon. After the comment, I knew that a weapon was being wielded against anyone who cared about a recognition of "important difference, critical need" in higher education. I also wondered how such a recognized scholar in the area of measurement could have misapplied one of the first rules of interpreting statistical analyses: correlation does not equal causation.

More to my horror, no one on the panel or in the audience interrupted the first speaker's diatribe. He simply went on with his analogy until the end of his presentation and sat down. The next speaker was introduced as though nothing out of the ordinary had happened during the session. My eye contact with other persons of color seated around the room was my only clue that something quite painful to many of us had actually occurred (Johnsrud \& Sadao, 1998). My reaction (now more 
fleeting after years of developing scar tissue to cover the wounds) was, "Is doing this work really worth it?” (Comás-Díaz \& Greene, 1994; Rains, 1998).

I was not completely dismayed, however. My colleague was introduced to speak next, and I was certain that he would address this issue. I was mistaken. The colleague provided a counterpoint to the first speaker's position but slipped into the same analogy to develop his argument.

I left before the third speaker began her remarks because I knew that I could no longer stay in the room without stopping the session (or being ejected from it). The reality was that it was not my role to stop a process considered perfectly respectable to the majority of POD members. To paraphrase an African proverb, "I was a guest in your house." It also became quite clear to me that this organization, in the aggregate, was still in the "Old Boy's Club" stage of organizational development in terms of diversity issues (Katz \& Miller, 1993). As that stage is usually the first of eight stages of multicultural organizational development, I realized that POD as an entity would need to participate in some very serious organization-wide discussions for diversity to be fully addressed. The question of "Where were my allies?" kept coming to mind as I left the plenary hall surrounded by several other individuals of color who had also left the session because they had also been offended by the first speaker's remarks.

Later, I learned that a brave soul in the audience had stood up at the end of the session and raised a question about the appropriateness of the first speaker's analogy. By that time, however, I was staring out of the window of my hotel room, looking at the mountains, and engaging in a forgiveness exercise in hopes that I could return to the conference and participate in the next workshop session with my CRLT colleagues.

\section{On Forgiving}

Research on persons of color in professional positions has yielded a great deal of information about the physical, emotional, and psychological toll of working within, and interacting with the wider society (ComásDiaz \& Greene, 1994; Hurtado, 1996; Jordan, 1997). Having focused my scholarship on women of color, I have learned a great deal about how holding rage rather than engaging in forgiveness negatively impacts one's ability to work effectively in the wider society (hooks, 1994; Hurtado, 1996; Jordan, 1997; Lewis, 1999). With the guidance and support of a very distinguished teacher and friend, I have developed a three-part forgiveness ritual that I use when it is appropriate to do so. First I forgive myself for ways in which I may have hurt myself in thought, word, deed, 
action, or reaction. I then forgive those who have hurt me in any of the same ways. Finally, I ask the forgiveness of those whom I have hurt.

While looking at the mountains, then, I forgave myself for the intensity of my reaction to the plenary speaker's provocations because I had encountered this type of behavior all of my life, beginning with segregated buses as a young child in the South. Next, I forgave the speaker for his need to destroy others out of his own fear of change. Finally, I asked the forgiveness of my ancestors for once again spending time working outside of my community when there is still so much to be done within it. After completing the acts of forgiveness, I realized that it was time to go to the CRIT workshop and help to model an intergroup dialogue.

\section{Where Were My Allies?}

Our CRLT-sponsored workshop following the luncheon session was titled "You Say 'Multicultural,' I say ..." The room I entered was full and, as the session began, became quite crowded, with standing room only. Among the framing questions those of us who had organized this workshop had offered was, "In what ways do we feel committed to, ambivalent about, or adverse to a multicultural approach in our work?” As we began the session with a brief closed fishbowl demonstration, each of us struggled aloud with how we had responded internally and externally to the preceding session. I raised aloud the "Where were my allies?" question that had left the room with me earlier in the afternoon. Others participating in the fishbowl spoke candidly of not knowing how to respond to the incident, feeling distressed about the ways in which the incident was affecting their colleagues and themselves, and wondering how the incident would impact on POD's ability to become a more diverse organization.

The workshop came at the appropriate point in the program, as many individuals wished to speak in the open fishbowl about their experience of the previous two hours. CRLT staff facilitated the discussion and made it possible for a large group of individuals to think collectively about what had happened and what it meant professionally and personally to each person.

Faculty attempting to manage emotionally volatile or stressful situations in the classroom can also use this technique of stopping to process the preceding statement, discussion, or incident with the class membership as a way of addressing rather than avoiding conflict about the topic. It requires faculty members to think ahead about the potential sources of conflict in the learning situation and to prepare themselves for them as 
well as help facilitate discussions so that they serve as learning experiences for the students. While, as noted earlier, I have been trained to do this work, I had such little knowledge of the actual situation that my emotional response to it would have been problematic had it not been for my skilled colleagues who could shape the afternoon into a valuable lesson for all of us.

\section{Ray of Light One: Interpersonal Relationships and Diversity}

Immediately following the workshop, I asked the colleague who had served on the panel if I might speak with him. He immediately agreed, although my reaction to his behavior on the panel had been shared with him after the plenary. He said that he hadn't recognized the impact of the first speaker's words, as he was trying to address the fallacies in that speaker's analysis. I told him that the first speaker's inappropriate behavior was less of a concern to me than his non-response to it. During our discussion, my colleague noted that the first speaker's remark had gone over his head. This led to my summation of the literature on the outcomes of being unconscious about racism-when things go over one's head.

Acts of overt and covert discrimination negatively affect interactions between members of target and agent groups (Zúñiga \& Nagda, 1993). Acts of covert discrimination can be particularly problematic in that exclusionary behaviors, policies, and procedures woven into daily interactions faced by the target group are ignored by members of the agent group (Bell, 1997; Figueira-McDonough, 1998; Icard, Jones, \& Wahab, 1999; Lubiano, 1996). Membership in one target group does not automatically permit an understanding of all target groups (Frankenberg, 1993). Those interested in supporting the inclusion of faculty of color in academia need to be aware of the daily experiences with overt racism and the ways in which these contribute to the turnover in some educational institutions (Antonio, 1998; hooks, 1994; Chan \& Hune, 1998). The development of a critical consciousness is required of those who desire to work toward inclusion of populations of color in the classroom, workplace, and wider society (Gutiérrez \& Lewis, 1999; Reed, Newman, Súarez, \& Lewis, 1997).

While my colleague was beginning to understand the impact of the incident on our interpersonal relationship, the full impact of the situation became clear to him when I began to tell him about several young people of color from our community whom he remembered as bright and generous children who were now in trouble with the law or had dropped out of school. My colleague appeared both horrified and 
deflated as he apologized profusely because he then fully "got it." In hindsight, I realized that until my colleague "got it," I was unable to "get over it" and stop mourning the incident. Sometimes people just need to be heard and have their experience validated.

\section{Ray of Light Two: Moving Diversity from the Margins ... 1}

Organizational leadership has an important role to play in the support of the retention of faculty from diverse backgrounds. Family leave policies, stopping tenure clocks after the birth of a new child, and providing writing leaves for those who are disproportionately called upon to work with diverse student groups or to represent diverse viewpoints in faculty governance situations are all mechanisms developed within educational institutions to recognize the unique experiences of diverse faculty members (Patchen, 1999; Project on Campus Community and Diversity, 1994; Statham, Richardson, \& Cook, 1991).

In addition to long-term strategies to foster diversity, there are shortterm and more immediate activities that can be undertaken by professional, organizational leadership in higher education. Recognizing that sometimes "teachable moments" present themselves in ways not included in the agenda of a meeting or conference, organizational leaders can embrace those moments as ways to build the organization's awareness and strengthen its membership base. The POD leadership took a courageous stance for a group unaccustomed to struggling organizationally with diversity issues in their activities during the second evening of the conference.

At the end of the dinner, POD's President announced to all assembled that instead of the scheduled talent show, the participants would undertake a "difficult dialogue," necessary because of the events of the afternoon. She noted that she would provide a ten-minute break between the end of the dinner and the beginning of the discussion so that those interested in leaving might do so.

By 8:00 p.m., approximately $40 \%$ of the participants who had attended the dinner left the room so as not to have to participate in the "difficult dialogue." Rather than viewing this as a "glass half empty," the POD leadership committed to fostering diversity within the organization could be cheered that $60 \%$ of those attending the event thought it important to attend and participate in the dialogue. This number was operationally, if not statistically, significant in that the number remaining in the room was more than enough to mount and sustain a diversity movement within the organization. 
During the public commentary (held after small group discussions at individual tables in the dining room), my long-time colleague with whom I'd had the conversation earlier in the afternoon stood up and apologized to the audience for not speaking up during the panel discussion. This apology was extremely significant for several first-time participants-especially for a South African scholar attending his first conference in the US after helping to develop educational programming in South Africa and the UK, and a group of feminist researchers who were also at POD for the first time. These individuals had sought out one another (and me) to discuss the events of the day and frame our responses to our continued involvement with the organization. Some of the first-time participants who had been working on issues of diversity for some time on their home campuses and in other professional organizations also noted that the evening's activity had brought a light to what had otherwise been a very disheartening week in terms of diversity issues on college campuses. Matthew Shepard, an undergraduate student member of the Gay/Lesbian Alliance at the University of Wyoming, had very recently been brutally beaten, tied to a fence, and left to die by two men in a heterosexist hate crime. Matthew, after struggling to live for three days, had died earlier that afternoon. The lyrics "You have to be carefully taught" reverberated for some of us, both in terms of the despair of losing another student from a diverse background as well as the hope of being involved with an organization making first steps toward recognizing the importance of that diversity for both the organization and those academic community members it served.

\section{Ray of Light Three: The Allies Find Their Voices}

Following the incident, the Conference's Chairperson located the plenary speaker who had stimulated the controversy. She pointed out the inappropriate nature of his actions and requested that an apology be made in writing to the membership. The individual promised to submit a letter and it was included in the conference's newsletter the next day.

The reprinted letter did not apologize; rather it simply stated the point (which wasn't done at the conference presentation) that "The analogy between racism and pedagogical stereotyping upset some people. Perhaps that's the best way to get people thinking about it. . . . We have duties we must perform. There are many ways to do that, and our style is our chosen way to do it. Don't judge us by appeal to style generalizations, that's stereotyping."2 
Cognizant of the tone of the speaker's letter and of the importance of taking a public stance on diversity within POD, the Program Chair placed a note at the bottom of the plenary speaker's letter: “The use of an analogy-especially when charged with highly emotional content and when the transfer to a different context is not elaborated and made explicit-can produce hurt and severe misunderstandings. I believe that [the speakers]'s argument (above) strongly supports the position that the use of racial identity in personnel decisions is not only inappropriate but highly unethical."

Also included in the following day's POD conference newsletter, distributed at the final luncheon session, was a letter from two POD members. I was gratified to note that they were from my academic institution. They commented:

This newsletter contains a response from [the speaker] who was asked by POD to respond to the offensive example he made in his address. However, we as POD members need to ask all of us to respond as well. This situation comes up in classrooms all the time, and we counsel faculty that it is their responsibility to respond-that inaction is action. Yet we all sat through the remainder of the address, taking no action ourselves. Why? We know the consequences on individuals, on the collective, as well as on the learning process-although many of us stayed in the room, we were not really able to engage in the rest of this program. How can we talk about this? How can we hold ourselves and our organization to the same standards we hold faculty and our institutions? Especially those of us who are white. Too often our strategy is to let people of color (or whoever is being victimized in a situation) take the lead and bear the responsibility. We too often think we can afford to wait and just do something different later, the next time... But we can't. Thank you to Ann for her courage. But all of us, especially white people, need to know our own responsibility to have addressed [this issue] even sooner and to find our own courage.

Within two days the POD organization had, through its conference and committed membership, moved the topic of organizational diversity from a non-existent, "false peace" stance to one where those holding different opinions had begun to struggle with the implications of 
recognizing and including topics of diversity for the organization and its membership. It moved, using the Katz and Miller (1993) conceptual framework, from an "Old Boy's Club" to the beginnings of a multicultural organization, skipping several stages along the way. While it would have been tempting to think that the group had "crossed the bridge" to "important issues," organizational change does not occur that easily. POD members will have to revisit some of those less enjoyable stages in the process with the $40 \%$ of the membership who left the dialogue during the second night and others like them. Nonetheless, individual and organizational transformations had begun to take place.

\section{Ray of Light Four: External Support of an}

Organizational Transformation

All allies supporting organizational transformation do not have to be found within the boundaries of the organization itself. When given the opportunity to reflect on the utility of incorporating issues of diversity into the activities of an organization or educational institution, surprising external allies sometimes emerge.

The keynote speaker for the final plenary of the conference on its last morning was Margaret Wheatley, author of the well regarded text Leadership and the New Science: Learning About Organization from an Orderly Universe (1992). POD had apparently been attempting to arrange for Wheatley to speak for several years, and some had remarked that the conference site was chosen with her in mind. From the program: "In part because Snowbird is in Wheatley's 'backyard,' we are able at this POD conference to engage one of the decade's brightest, most creative thinkers about purposeful organizations and their renewal and change. Meg Wheatley's keynote address and conversation group at the conference are ones you won't want to miss."

Unknown to many of us, Wheatley had attended and participated in some of the conference proceedings (including the dialogue facilitated by my colleagues from CRLT) and had been affected by the events of the preceding two days. Rather than giving her originally scheduled speech, she changed her presentation to address the experiences of the preceding two days as possibilities for growth and transformation. Her presentation provided additional information for those POD members who had committed themselves to fostering diversity within the organization and at their home institutions. It was also new information to that $40 \%$ of the audience who had not participated in the "difficult dialogue" but had yearned to hear her speak. Her speech demonstrated that diversity was not a marginal issue but one central to those of us who are committed to 
building communities reflective of our "different" life experiences. What a wonderful way to end this conference!

As I boarded the airplane bound for Minneapolis I wondered whether POD could hold onto the momentum that the conference experience had generated. Would those who had begun to recognize "a need" to address forms of diversity be supported by the organization in their moves from a "no difference" stance? Could the organization identify ways to make difference a central issue to be addressed in all aspects of its work and not a marginal one? Could fledgling bridges built between the new POD members of racial and ethnic groups of color be strengthened? Could those POD members who remained firm in their "no difference, no need" stances maintain their participation in the organization? Would it be possible to move the issue of diversity from the bottom of the priorities list for faculty developers?

In doing organizational development work around the issue of diversity, I generally recommend that a small group of individuals be constituted, representing all levels off the organizational membership and divergent viewpoints on the topic of diversity in the context of the organization. That group would be charged with the movement of the diversity agenda (as operationally defined by the organization) for the organization. Acting as a core team, the group would be responsible for developing a set of actions expected of the organization's mission, its administrative leadership, and its membership. The same core team would monitor the organization's progress on its diversity initiative and would report outcome data to its membership and to the larger society through the development of papers for publication and dissemination.

\section{"Saving our Faculties" or the Role of Faculty Development Programs for People of Color}

\section{Saturday, October 18, 1998-Joining the Choir}

There is something interesting about coming back home to the places that shaped one's career trajectory in diversity work. Minneapolis/St. Paul is one of those places for me. My first faculty development seminar presentation was in November 1972, when I was sent by the administration of the university to meet with teachers (not all faculty) in northern Minnesota to speak on diversity issues. The reception was typical for the times in that the predominantly male audience spent their hour with me staring out of the window, placing their feet on the seats in front of them, and generally ignoring the materials we were working through. At the 
time, those wishing to fulfill their credentialing process needed simply to attend rather than participate in diversity training seminars. I remember wondering what young people this group of teachers was likely to influence and knowing how little I would value being in their classrooms.

The Twin Cities also gave me a number of role models for excellence in faculty development programs pertaining to diversity issues. One of those individuals was Professor Josie Johnson who, at the time, was a faculty member in the new department of Afro-American studies. Within minutes of arriving at the Saving Our Faculties conference, I was in a conversation with a woman who looked familiar to me (and I to her). It wasn't until we exchanged names that I realized I was speaking to the same Professor Johnson, former University Vice President and former Regent, now retired but still working tirelessly for faculty and students on the University of Minnesota campus. Others from my faculty development "home" had also gone on to prestigious positions within the system of higher education institutions in the state including two former classmates-a Dean of the General College at the University and his wife, Vice President of the Minneapolis Community and Technical College System. We were, in some respects, a significant reason faculty of color remained in higher education 30 years before, and as we became reacquainted, realized that we were serving that same function for faculty and students of color in our respective institutions. The mentors who were our allies had prepared us to become allies for the next generation of faculty and staff. As a first-generation college student myself, mentorship from human beings who shared similar historical and political, if not social, backgrounds was particularly significant to me. Returning to Minnesota for this conference was an opportunity to surround myself with allies and have opportunities to discuss rather than explain.

\section{Ray of Light Five: Participants-When the Marginal Are the Center} At a conference on the recruitment and retention of faculty of color in higher education held in October in Minnesota, one might expect heavy representation from local institutions. Interestingly enough, this conference truly had national representation from colleges and universities and from national educational organizations. Faculty and administrators from 92 institutions of higher education attended-from as far away as the University of Hawaii. Organizations monitoring the activities of higher education such as the American Association of University Professors, South Carolina Commission on Higher Education, the Association of American Colleges and Universities, the Council on Asian Pacific 
Minorities, and the Michigan Department of Education were also represented.

With 92 institutions represented, this faculty development conference attracted some of the more prominent faculty of color interested and engaged in diversity work. The conference offered an opportunity to meet and talk with Professors Gloria Holguín Cuádraz (featured in the video Shattering the Silences) and Samuel Myers, Jr. (whose early research in economics on the underrepresentation of Black women in past censuses challenged the conventional wisdom about actual and modeled poverty data). The conference also drew Frances Rains, a woman of color from both a First Nations and Asian background whose work I have respected for a long time. In each case of working with these individuals and others during the three days of the meeting, participants were gracious and graceful with one another, receiving new persons as though the person was a family member. That sense of goodwill was a source of conversation between myself and another individual who had attended the POD conference. Many of us noted at the end of the Minnesota meeting that it had been a source of support making it somewhat easier to return to our home institutions.

\section{Ray of Light Six: Grounded in the Research}

The Saving Our Faculties Conference offered a wealth of new research on the faculty development needs of faculty of color. The plenaries and workshops introduced participants to the evidence-based situations confronting faculty of color as they seek tenure and/or retention in higher educational institutions. There was no dearth of scholarly presentations debunking the myths about why there are so few faculty of color in most higher educational institutions in the US (Davis, 1998; Smith, 1998). Those for whom research requires multivariate analysis would have had their needs met by Antonio's (1998) analysis of faculty retention factors, Turner's (1998) research on issues related to promotion and tenure of faculty of color, and Kenyon and Hune's (1998) study of factors supporting the recruitment and retention of Asian Pacific Islander faculty and students, among others. Myers' presentation, Diversity Seen from the Top and Bottom, based on national data noted that "A high minority faculty development budget is the single most important factor to increased minority hiring. Its effect is greater than the combined effects of 'excellent diversity' and increased funding for minority faculty recruitment" (1998, slide 26). As I listened to the presentations over the three days, I was reminded of a former colleague's insistence that no scientific 
evidence existed that diversity had any impact on learning outcomes. While the methodologies now exist to understand the nuances of classroom and institutional climates with regard to multiculturalism, the contrast between the presence of these studies at this conference and their absence at the last one was striking to me.

Allies were also found in the workshops presented during the conference. One session was hosted by faculty developers who would ordinarily have been at the POD conference. Their presentations focused on two faculty development programs in different parts of the country (one for women, one for people of color) and the politics of designing and keeping such programs open. Workshop presenters were quite candid about the obstacles they faced on their respective campuses with regards to diversity or multicultural issues: faculty, staff, and students.

\section{Endings and Transformations}

Although the majority of the conference participants were leaving the Twin Cities, we were also aware that a set of relationships had been forged that would not quickly be forgotten. We had participated in an event that could refresh and sustain rather than limit. As a final act, the participants were asked to record the moment by posing for a photograph. I have participated in taking photographs at conferences before but have only had the experience of everyone's willingness to be photographed in meetings where the participants have known and developed relationships with one another. By the end of these three days it seemed clear that relationships between participants-those of color and those from original European lineage-had been forged.

Lest the rich information presented at the conference be lost, organizers arranged to forward the conference proceedings to each participant. Now we have a set of documents that focus on the specific needs and experiences of faculty of color. The document is a useful tool for raising the unique faculty development needs of faculty of color within our home institutions.

As at the POD conference, when I left the Saving Our Faculties conference I knew transformation had taken place for many participants. At the very least, this transformation could validate our "healthy cultural paranoia" as an adaptive method given our experiences raising diversity issues on our respective campuses (whether we were or were not people of color). At the most, many of us learned what was possible for faculty development programs when issues of diversity were addressed rather than ignored. 


\section{Lessons Learned About Moving Across the Bridge}

During those six days in October, I was able to move from one end of the bridge to the other. One end was exhilarating and challenging because it framed the work that had already been done on faculty development issues for faculty of color and identified the critical need for more work in the area. The other end of the bridge was also challenging as it framed the dearth of empirical evidence supporting the "no difference, no need argument."

Those of us who choose to do faculty development work addressing the needs of faculty of color will periodically find ourselves on both ends of the bridge. While some of us might attempt to strive to remain in the center, there are some lessons to be learned from those end places:

1) We can recognize reactance as an expected outcome of the introduction into our work of content about the faculty development needs of faculty of color. In this respect, backlash can have positive as well as negative effects. Our lesson as faculty development professionals is, to paraphrase Johnson Reagon (1999), that "stepping across our safety zone is necessary."

2) We must note that allies in the expected places are a source of renewal. Allies in unexpected places are a gift promoting growth within an educational institution or professional organization. External allies can support our work and, once identified, should be nurtured.

3) Methods such as intergroup dialogues, focus groups, and fishbowls are useful in airing potentially volatile subjects.

4) Faculty development professionals working on diversity issues will need to balance individual and institutional needs, experiences, and interventions for themselves and those with whom they work.

5) There is a need for faculty development work focused solely on the unique experiences of faculty and students of color.

6) Sometimes the margins are a good place to be!

\section{ENDNOTES}

'This phrase is adapted from bell hooks. (1990). Choosing the margins as a space of radical openness. In Yearming: Race, gender, and cultural politics (145-153). Boston, MA: South End Press.

${ }^{2}$ The three quotes in this section are drawn from the POD newsletter distributed to conference participants on the third morning of the conference. Names were omitted by the author. 


\section{REFERENCES}

Adams, M. (1992). Cultural inclusion in the American college classroom. In L. L. B. Border \& N. V. N. Chism (Eds.), Teaching for diversity (pp. 5-17). New Directions for Teaching and Learning, No. 49. San Francisco, CA: JosseyBass.

Antonio, A. L. (1998, October). Faculty of color reconsidered: Retaining scholars for the future. Proceedings of Keeping Our Faculties: Addressing the Recruitment and Retention of Faculty of Color in Higher Education. Minneapolis, MN: Office of the Associate Vice President for Multicultural and Academic Affairs, University of Minnesota.

Bell, L. A. (1997). Theoretical foundations for social justice education. In M. Adams, L. A. Bell, \& P. Griffin (Eds.), Teaching for diversity and social justice: $A$ sourcebook (pp. 3-15). New York, NY: Routledge.

Bell, L. A., Washington, S., Weinstein, G., \& Love, B. (1997). Knowing ourselves as instructors. In M. Adams, L. A. Bell, \& P. Griffin (Eds.), Teaching for diversity and social justice: $A$ sourcebook (pp. 299-310). New York, NY: Routledge.

Chan, K. S., \& Hune, S. (1998, October). Finding and keeping Asian and Pacific Americanfaculty. Presentation at the Saving Our Faculties Conference, Minnesota.

Comás-Díaz, L., \& Greene, B. (1994). Women of color with professional status. In L. Comás-Diaz \& B. Greene (Eds.), Women of color: Integrating ethnic and gender identities in psychotherapy (pp. 347-388). New York, NY: Guilford.

Davis, J. D. (1998, October). Retaining faculty of color: The five habits of a highly effective institution. Proceedings of Keeping Our Faculties: Addressing the Recruitment and Retention of Faculty of Color in Higher Education. Minneapolis, MN: Office of the Associate Vice President for Multicultural and Academic Affairs, University of Minnesota.

Figueira-McDonough, J. (1998). Toward a gender-integrated knowledge in social work. In J. Figueira-McDonough, R. E. Netting, \& A. Nichols-Casebolt (Eds.), The role of gender in practice knowledge: Claiming balf the buman experience (pp. 3-40). New York, NY: Garland Publishing.

Frankenberg, R. (1993). The social construction of whiteness: While women, race matters. Minneapolis, MN: University of Minnesota Press.

Gutiérrez, L., \& Lewis, E. (1997). Education, participation, and capacity building in community organizing with women of color. In M. Minkler (Ed.), Community organization and community building for bealth (pp. 216-229). New Brunswick, NJ: Rutgers University Press. 
Gutiérrez, L., \& Lewis, E. (1999). Bringing an empowerment perspective into organizational practice. In L. Gutiérrez \& E. Lewis (Eds.), Empozering women of color (pp. 80-99). New York, NY: Columbia University Press.

hooks, b. (1993). Sisters of the yam: Black women and self-recovery. Boston, MA: South End Press.

hooks, b. (1994). Teaching to transgress: Education as the practice of freedom. New York, NY: Routledge.

Hurtado, A. (1996). The color of privilege: Three blasphemies on race and feminism. Ann Arbor, MI: University of Michigan Press.

Icard, L., Jones, T., \& Wahab, S. (1999). Empowering lesbian and bisexual women of color: Overcoming three forms of oppression. In L. Gutiérrez \& E. Lewis (Eds.), Empowering women of color (pp. 208-225). New York, NY: Columbia University Press.

Johnson Reagon, B. (1999, March). Septima Clark and the sweetness of struggle. Keynote presentation for the Center for the Education of Women, University of Michigan, Ann Arbor, MI.

Johnsrud, L. K., \& Sadao, K. C. (1998). The common experience of "otherness": Ethnic and racial minority faculty. The Review of Higher Education, 21 (4), 315-342.

Jordan, J. (1997). Women's growth in diversity: More weritings from the Stone School Center. New York, NY: Guilford.

Kaplan, Matthew (Ed.). (1998). To Improve the Academy, 17.

Katz, J., \& Miller, F. A. (1993). Cultural diversity as a developmental process: The path from monocultural club to inclusive organization. New York, NY: The Kaleel Jamison Consulting Group.

Kenyon, C., \& Hune, S. (1998, October). Towards creating a successful climate for Asian Pacific American female faculty. Proceedings of Keeping Our Faculties: Addressing the Recruitment and Retention of Faculty of Color in Higher Education. Minneapolis, MN: Office of the Associate Vice President for Multicultural and Academic Affairs, University of Minnesota.

Lewis, E. A. (1993). Continuing the legacy: On the importance of praxis in the education of social work students and teachers. In D. Schoem, L. Frankel, X. Zúñiga, \& E. Lewis (Eds.), Multicultural teaching in the university (pp. 26-36). New York, NY: Praeger.

Lewis, E. A. (1999). Staying on the path: Lessons about health and resistance from women of the African Diaspora in the United States. In L. Gutiérrez \& 
E. Lewis (Eds.), Empowering women of color (pp. 150-166). New York, NY: Columbia University Press.

Lubiano, W. (1996). Like being mugged by a metaphor: Multiculturalism and state narratives. In A. Gordon \& C. Newfield (Eds.), Mapping multiculturalism (pp. 64-75). Minneapolis, MN: University of Minnesota Press.

Myers, S. L., Jr. (1998, October). Diversity seen from the top and bottom. Proceedings of Keeping Our Faculties: Addressing the Recruitment and Retention of Faculty of Color in Higher Education. Minneapolis, MN: Office of the Associate Vice President for Multicultural and Academic Affairs, University of Minnesota.

Patchen, M. (1999). Diversity and unity: Relations between racial and ethnic groups. Chicago, IL: Nelson-Hall.

Peterson-Hickey, M., \& Stein, W. (1998, October). Minority faculty in academe: Documenting the unique American Indian experience. Proceedings of Keeping Our Faculties: Addressing the Recruitment and Retention of Faculty of Color in Higher Education. Minneapolis, MN: Office of the Associate Vice President for Multicultural and Academic Affairs, University of Minnesota.

Project on Campus Community and Diversity. (1994). Dialogues for diversity: Community and etbnicity on campus. Phoenix, AZ: Oryx.

Rains, F. V. (1998, October). Is the price worth the cost of survival in academic apartheid? Women faculty of color in a [white] research university. Proceedings of Keeping Our Faculties: Addressing the Recruitment and Retention of Faculty of Color in Higher Education. Minneapolis, MN: Office of the Associate Vice President for Multicultural and Academic Affairs, University of Minnesota.

Reed, B. G., Newman, P. A., Súarez, Z., \& Lewis, E. (1997). Interpersonal practice beyond diversity and towards social justice. The importance of critical consciousness. In C. Garvin \& B. Seabury (Eds.), Social work practice (pp. 4477). New York, NY: Garland.

Rooney, R. (1992). Practice strategies for work with involuntary clients. New York, NY: Columbia University Press.

Schoem, D., Frankel, L., Zúñiga, X., \& Lewis, E. (Eds.). (1993). Multicultural reaching in the university. New York, NY: Praeger.

Smith, D. G. (1998, October). Achieving faculty diversity: Debunking myths and other strategies. Proceedings of Keeping Our Faculties: Addressing the Recruitment and Retention of Faculty of Color in Higher Education. Minneapolis, MN: 
Office of the Associate Vice President for Multicultural and Academic Affairs, University of Minnesota.

Statham, A., Richardson, L., \& Cook, J. A. (1991). Gender and university teaching: A negotiated difference. Albany, NY: State University of New York Press.

Turner, C. S. V. (1998, October). Promotion and tenure for faculty of color: Promoting business as usual. Proceedings of Keeping Our Faculties: Addressing the Recruitment and Retention of Faculty of Color in Higher Education. Minneapolis, MN: Office of the Associate Vice President for Multicultural and Academic Affairs, University of Minnesota.

Wheatley, Margaret. (1992). Leadership and the new science: Leaming about organization from an orderly universe. San Francisco, CA: Berrett-Koehler.

Wright, D. (1998, October). Faculty development centers in research universities: $A$ study of resources and programs. Paper presented at the meeting of the Professional and Organizational Development Network in Higher Education, Snow Bird, UT.

Zúniga, X., \& Nagda, B. A. (1993). Dialogue groups: An innovative approach to multicultural learning. In D. Schoem, L. Frankel, X. Zúñiga, \& E. Lewis (Eds.), Multicultural teaching in the university (pp. 233-248). New York, NY: Praeger.

\section{Contact:}

Edith A. Lewis

3688 Social Work

University of Michigan

1080 South University

Ann Arbor, MI 48109-1106

(734) 763-6257

(734) 936-1961 (FAX)

edithl@umich.edu

Edith A. Lewis is Associate Professor of Social Work and Women's Studies. She received her M.S.W. from the University of Minnesota (1975) and her Ph.D. in Social Welfare from the University of Wisconsin, Madison (1985). She has taught in the areas of cultural competence in interpersonal practice, family relationships, group process, behavioral theories and interventions, international social work, and community and social systems practice. Her intervention research has focused on using the strengths of populations of color to inform social work practice, policy, and research. Her publications include two 
co-edited books, Empowering Practice with Women of Color and Multicultural Teaching in the University, as well as numerous articles on topics that include teaching about families, community organizing with women of color, and feminist perspectives on community organizing with women of color. She is currently completing a book of case studies and exercises to be used by African and US social work students. 